\title{
The Functional Properties of Bread Enriched with Essential Fatty Acids
}

\author{
Lamazhapova Galina Petrovna ${ }^{1,2^{*}}$, Syngeeva Erzhena Vladimirovna1, Zham- \\ saranova Sesegma Dashievna, ${ }^{1,2}$, and Kozlova Tatyana Sergeevna ${ }^{1}$ \\ ${ }^{1}$ East Siberia State University of Technology and Management \\ 2 Banzarov Buryat State University \\ ORCID \\ Lamazhapova Galina Petrovna; 0000-0002-4118-215X
}

Corresponding Author:

Lamazhapova Galina Petrovna; email: lamazhap@mail.ru

\section{Dates}

Published 13 January 2022

Publishing services provided by Knowledge E

(c) Lamazhapova Galina Petrovna et al. This article is distributed under the terms of the Commons Attribution License, which permits unrestricted use and redistribution provided that the original author and source are credited.

Selection and Peer-review under the responsibility of the 8th Scientific and Practical Conference Conference Committee.

\section{G OPEN ACCESS}

Abstract. We developed $\omega$-3-enriched bread by adding a liposomal polyunsaturated fatty acids (PUFAs) concentrate to the bread recipe. We determined that subsequent feeding of the $\omega$-3-enriched bread to experimental animals in the alimentary dyslipidaemia state led to normalisation of the lipid profile of the blood serum, with a decrease in the total cholesterol, triglycerides, and low-density and very lowdensity lipoproteins. The high-density lipoproteins, antioxidants, reduced glutathione and glutathione reductase activity index increased compared to the corresponding indicators in animals with alimentary dyslipidaemia that were fed bread without $\omega-3$. The $\omega$-3-enriched bread diet significantly decreased harmful oxidation products (diene conjugates and malondialdehyde) in the blood plasma, erythrocytes and liver. Therefore, the results suggested that bread enriched with $\omega-3$ fatty acids is a functional food with hypolipidaemic action. The results on the total content of fatty acids in lipids from bread samples prepared according to a standard recipe and bread enriched with concentrate showed that the relative content of omega-3 PUFAs in the fortified bread significantly increased by 3.2 times compared to bread without the addition of concentrate. The additive did not change the consumer qualities of the finished product (taste and smell of the bread).

Keywords: alimentary dyslipidaemia, antioxidant effect, bread, functional food, lipid profile, $\omega-3$ polyunsaturated fatty acids

\section{Introduction}

Due to a number of objective reasons our diet has ceased to meet the optimal nutritional requirements of a healthy body. The observed imbalance in the nutrition structure of the population is one of the reasons for the mortality increase from chronic non-infectious diseases [36]. This demonstrates the need for healthy food products with high nutritional and biological value. In order to preserve the health of a modern human being, functional foods, generally defined as whole, fortified, enriched or enhanced foods that provide additional health benefits [5], should be widely implemented in all segments of the population. 
The $\omega-3$ fatty acids are unique in their effectiveness, preventive and curative properties [28]. Eicosapentaenoic (EPA), docosahexaenoic acid (DHA) and other $\omega-3$ PUFAs are important structural components of cell membranes. When incorporated into phospholipids, they affect various cell membrane attributes, such as permeability, flexibility and the activity of membrane-bound enzymes. They are also precursors in the biosynthesis of eicosanoids (lipid regulators) [19]. The level of eicosanoids synthesised in vivo depends on the composition and amount of fatty acids in the diet [6]. Consumption of $\omega-3$ PUFAs in the composition of products or biologically active additives is one approach to preventing cardiovascular diseases [8].

$\omega-3$ PUFAs can have a beneficial effect in vivo only if they are incorporated into the daily diet in appropriate amounts and in the optimal ratio with $\omega-6$ PUFAs [17]. In Russia, it is recommended to take $0.8-1.6 \mathrm{~g} / \mathrm{day}$ or $1-2 \%$ of the daily nutritional value of $\omega-3$ PUFAs and $8-10 \mathrm{~g} / \mathrm{day}$ or $5-8 \%$ of the daily nutritional value for $\omega-6$ PUFAs [25]. In Brazil, the National Health Surveillance Agency (ANVISA) believes that foods enriched with $\omega-3$ PUFAs should ensure intake of at least $0.1 \mathrm{~g}$ EPA and/or DHA per meal in $100 \mathrm{mg}$ or $100 \mathrm{ml}$, to be able to assert their functional properties [10]. In Europe, it is recommended a daily consumption of long-chain $\omega$-3 PUFAs (EPA+DHA) in amount of $2 \mathrm{~g} /$ day and $\omega-6$ PUFAs in amount of $10 \mathrm{~g} /$ day [32]. Despite the differences, the optimal $\omega-6 / \omega-3$ ratio in the daily diet is the same and is $5-10: 1$ in different documents.

Enrichment of commonly consumed foods with $\omega-3$ PUFAs is considered to be an innovative approach, which is most advantageous for the health of people that do not require major changes to their dietary habits [13]. Therefore, it is necessary to complement daily consumable products, such as butter, eggs and products thereof, pasta, sauces, juices, meat, and dairy products with $\omega-3$ PUFAs, obtaining thereby the so-called functional foods [12].

In various foods, such as bakery products, dairy and other products, addition of PUFAs has certain restrictions due to their susceptibility to oxidation, which can readily lead to the emergence of extraneous odours and, moreover, cause significant loss of quality of products, nutritional value and bioavailability [12]. In order to prevent the oxidation of PUFAs when delivering them in vivo, they need to be protected from the external environment. Particularly, encapsulation is widely used to mask the undesirable taste and odour of $\omega-3$ PUFAs and stabilise them against degradation and oxidation [2]. Most methods of microencapsulation of various bioactives used in the food industry are based on the use of a biopolymer matrix consisting of sugars, starches, proteins, dextrins and alginates [7]. From a biocompatibility perspective, liposomes are ideal carriers. They are formed from natural lipids and, therefore, are non-toxic, do not cause adverse immune 
reactions and are biodegradable, i.e. they are destroyed by conventional enzymes present in the body [1]. In the food industry, liposomes have been used for controlled delivery of diverse ingredients, such as proteins, enzymes, vitamins and fragrances [33].

Long-chain PUFAs are mostly found in the fats of fish, marine invertebrates and marine mammals. Research of the fatty acid composition of lipids of the Baikal seal showed that its liver and blubber are rich in PUFAs including the essential fatty acids (up to 4\% EPA) [18]. Previously, we obtained a PUFAs concentrate from the Baikal seal blubber by its complex formation with urea [37]. The content of $\omega-3$ PUFAs increased in the concentrate and the ratio of $\omega-6 / \omega-3$ in the obtained concentrate was 1.3:1. A method to incorporate the concentrate into liposomal structures was also proposed [37]. In a subsequent evaluation of the biological effectiveness of the liposomal PUFAs concentrate performed in an experimental rat model of diet-induced dyslipidaemia, we showed a decrease in the total cholesterol (TC; 48\%), triglycerides (TG; 35.9\%), and in the cholesterol of low-density (CLDL; 58.5\%) and very low-density (CVLDL; 70.3\%) lipoproteins in the blood serum of the animals [38]. Furthermore, the indicators of the cholesterol of high-density lipoproteins ( $\mathrm{CHDL}$ ) increased by $90 \%$, while the atherogenic index (Al) decreased 11.2 times compared to the animals fed the atherogenic diet only (no oral supplementation of the liposomal PUFAs concentrate) [38].

The current paper aimed to evaluate the influence of white wheat bread enriched with the liposomal PUFAs concentrate on the lipid profile and oxidative status of animal models of atherogenic dyslipidaemia.

\section{Materials and methods}

\subsection{Obtaining enriched bread}

We have previously described the methods for producing the liposomal PUFAs concentrate [37]. The $\omega$-3-enriched bread was prepared by introducing the liposomal suspension of the PUFAs concentrate into a white wheat bread recipe with partial replacement of the water. The required amount of water was calculated based on the moisture content of the flour.

\subsection{Acidic methanolysis of bread oil}

The oil in the bread samples was isolated by the Bligh and Dyer (1959) method. Acidic methanolysis of the oil contained in $100 \mathrm{mg}$ of sample was performed in $5 \mathrm{~mL}$ of $2 \mathrm{~N}$ 
$\mathrm{HCl}$ in methanol at $80^{\circ} \mathrm{C}$ for $45 \mathrm{~min}$. At this stage, fatty acids and aldehydes from the complex lipids are released in the form of methyl esters and dimethylacetals. These components were extracted with hexane $(400 \mu \mathrm{L})$ for $5 \mathrm{~min}$ and the resultant fatty acid methyl esters (FAME) analysed by gas chromatography-mass spectrometry (GC-MS) using an Agilent Packard HP 6890N gas chromatograph equipped with an HP-5MS column (0.25 umi.d.) and an HP MSD 5973N quadrupole mass spectrometry detector (Agilent, Santa Clara, USA). The injection volume was 1-2 $\mu \mathrm{L}$. Helium was used as the carrier gas at a constant flow rate of $1.5 \mathrm{~mL} / \mathrm{min}$. The column temperature programme was as follows: $125^{\circ} \mathrm{C}$ (isotherm $0.5 \mathrm{~min}$ ), followed by $125-320^{\circ} \mathrm{C}\left(7^{\circ} \mathrm{C} / \mathrm{min}\right.$, isotherm 0.5 $\mathrm{min})$. The evaporator temperature was $280^{\circ} \mathrm{C}$. The sample volume was $1 \mu \mathrm{L}$ with steam splitting 40:1.

\subsection{Experimental design to assess the biological activity of the product}

The biological effectiveness of the product was performed using 40 adult male Wistar rats weighing 130-150 g, which were obtained from the nursery of the Research Institute of Biophysics of the Angarsk State Technical Academy. Previously, all animals used in the experiment had a standard vivarium diet and water ad libitum. The experiments were conducted in accordance with the Rules of good laboratory practice in the Russian Federation (GLP) (approved by the Russian Ministry of Health, order N 267 of 19.06.2003).

The experimental hyperlipidaemia within rats was induced using the model of alimentary hypercholesterolemia (atherogenic diet) by introduction of cholesterol (BioChemica, AppliChem $\mathrm{GmbH}$, Germany) at a dose of $25 \mathrm{mg} / 100 \mathrm{~g}$ of the body weight of the rat and $5 \%$ lard of the total weight of the animals' diet, within 21 days into the typical diet.

The animals were divided into four experimental groups $(n=10)$ including group I intact (animals had standard feed and water); group II - control (the animals were on an atherogenic diet for 21 days); group III - «control bread» (animals had white wheat bread, produced according to a standard recipe daily, for 21 days after the atherogenic diet), and group IV - «test bread» (animals had bread, enriched with the liposomal PUFAs concentrate, daily for 21 days after the atherogenic diet). 


\subsection{Evaluation of hypolipidaemic effectiveness of bread}

In order to assess the hypolipidaemic effectiveness of the $\omega$-3-enriched wheat bread, we determined the TC, TG, CHDL, CLDL, and CVLDL in the blood serum of the rats using a Mindray BS-400 automatic biochemical analyser (China) and standard reagents obtained from Abris+ (Russia) and Dias (Russia).

The Al was calculated to describe the atherogenic blood properties, according to the following formula:

$$
\mathrm{Al}=\frac{T C-C H D L}{C H D L}(1)
$$

\subsection{Determination of oxidation products}

The concentrations of malondialdehyde (MDA) in the liver homogenates and in the serum were determined by the method of Mihara [26], which is based on the reaction of MDA with 2-thiobarbituric acid (TBA) (Sigma区- Aldrich, St. Louis, USA). The concentration of TBA-active products in the samples was measured spectrophotometrically at 535 and $570 \mathrm{~nm}$. The MDA content in the erythrocytes was obtained according to the method described by Ernster and Nordenbrand [11].

The diene conjugates (DCs) content in the erythrocytes was established according to the method of Placer (1968), modified by Gavrilov and Mishkorudnaya [14] for erythrocytes. The haemolysate of erythrocytes was shaken with a distilled solution of isopropanol:heptane (1:1), followed by addition of heptane. After $1-2 \mathrm{~h}$, the absorption spectrum of the mixture was recorded (232 nm) with a Cary 300 UV-vis spectrophotometer (Varian, USA). The extinction coefficient at $233 \mathrm{~nm}$ was $2.2 \times 10^{-5} \mathrm{~cm}^{-1} \mathrm{M}^{-1}$. The DCs in the blood plasma and the liver homogenate were determined by the classical method [35].

\subsection{Determination of the antioxidant activity of bread}

The amount of reduced glutathione (GSH) (Sigma-Aldrich, St. Louis, USA) was determined by the method of Beutler (1975) [3], based on the interaction of GSH with 5,5'dithio-bis-2-nitrobenzoic acid to form the yellow anion of 2-nitro-5-thiobenzoate, which was recorded spectrophotometrically at $412 \mathrm{~nm}$.

The GSH reductase activity was determined Glatzle [16] by monitoring the change in the oxidation rate of NADPH (GERBU Biotechnic GmbH, Germany), which was recorded spectrophotometrically as the decrease in optical density at $340 \mathrm{~nm}$. 


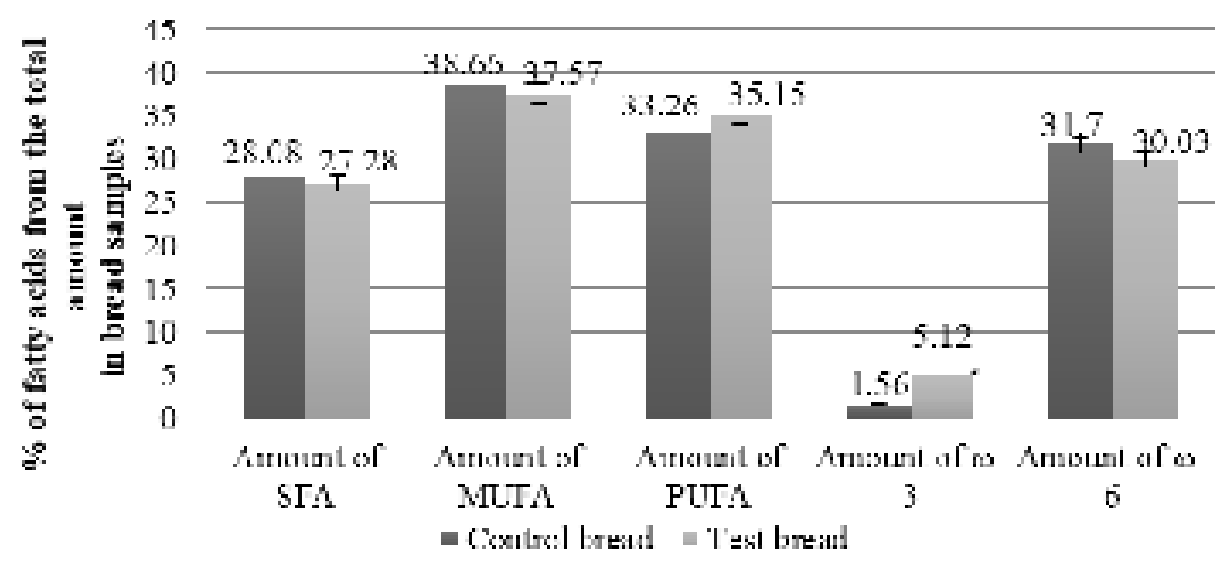

Figure 1: The total fatty acids composition in bread samples. Note: * - reliable deviation in the value in the «test bread» group compared to the value in the «control bread» group $(p \leq 0.05)$; SFA - saturated fatty acids, MUFA - monounsaturated fatty acids.

The total content of antioxidants (TCA) in the blood serum was amperometrically assessed using a Tsvetyauza-01-AA flow-injection system equipped with a plunger pump (Scientific Production Association, Khimavtomatika, Russia) at a working electrode potential of $1.3 \mathrm{~V}$ and an eluent feed rate of $1.2 \mathrm{~cm}^{3} / \mathrm{min}$. Gallic acid (Vecton Corp, Russia) was used as a standard. The repeatability indicator (relative root-mean-square deviation of repeatability) was $5 \%$.

All data were presented as means \pm standard deviation (means \pm SD) and evaluated by one-way ANOVA by IBM SPSS Statistics 19.0 (SPSS Inc., Chicago, IL) to detect intergroup differences. Differences were considered to be statistically significant if $p$ values $<0.05$.

\section{Results and discussion}

\subsection{Fatty acid composition of enriched bread}

As the liposomal PUFAs concentrate was in a suspension, its introduction to the bread recipe was done by replacing part of the water. Control samples were prepared according to the recipe without adding extra ingredients. The liposomal PUFAs concentrate was added to the test samples of wheat bread at $30 \mathrm{~g} / 100 \mathrm{~g}$ flour. The research data on the total fatty acid composition of lipids in various bread samples (control bread made according to the standard recipe, test bread enriched with the PUFAs concentrate) are presented in Figure 1.

The $\omega-3$ fatty acids content increased 3.2 times in the test sample compared to the control. Increasing the content of $\omega-3$ PUFAs changed the $\omega-6 / \omega-3$ ratio in the test 


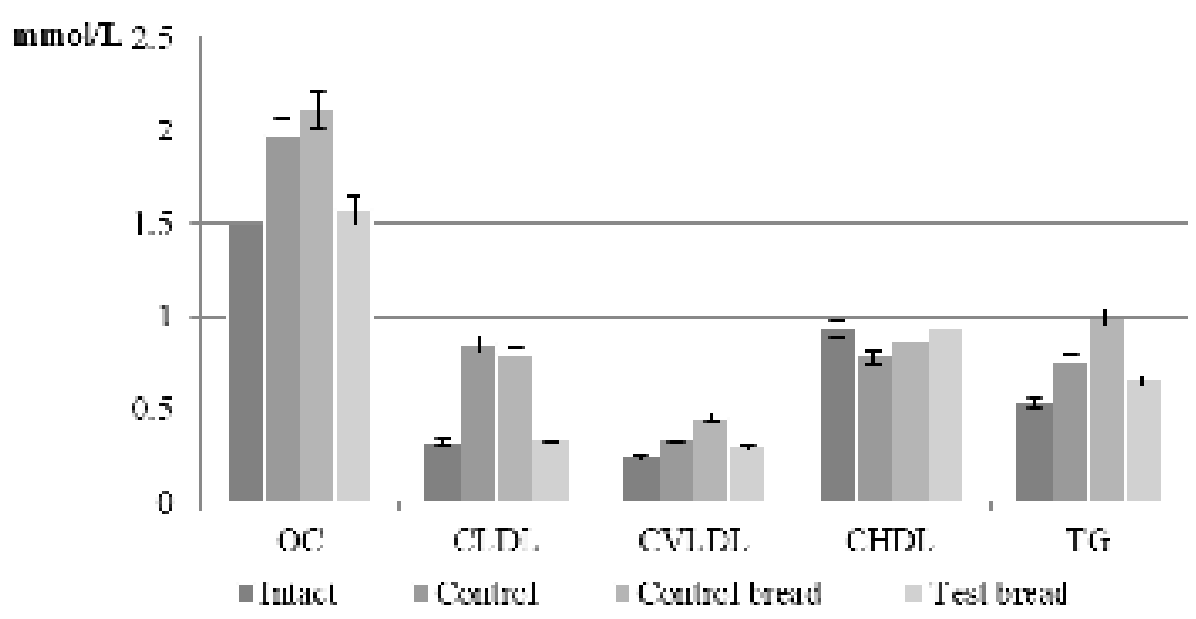

Figure 2: Effect of wheat bread enriched with the liposomal PUFAs concentrate on the lipid profile of the experimental animals.

bread, which was 5.8:1, whereas, in the control sample the corresponding ratio was 20:1. This addition does not alter the taste and aroma of bread and gave no foreign odours [24].

\subsection{Hypolipidaemic effect of enriched bread}

Figure 2 shows the lipid profile of the blood serum of animals in an experimental hyperlipidaemic state when fed with bread made according to a standard recipe and with the $\omega$-3-enriched bread. The TC content in the blood serum of animals on the atherogenic diet (control group) was $(p \leq 0.05)$ reliably increased by $24.36 \%$ relative to the intact group.

The TC content in the blood serum reliably increased by $29.38 \%$ when compared with the intact group, as a result of the atherogenic diet of the experimental animals treated with wheat bread prepared according to the standard. Perhaps a small increase in the total pool of cholesterol is associated with an increase in the proportion of synthesised cholesterol by adding bread to the diet. In contrast, the TC indices decreased by $25.47 \%$ within the animals treated with the $\omega$-3-enriched bread compared to the control group (atherogenic diet only). The introduction of bread enriched with $\omega-3$ fatty acids on the background of the atherogenic diet reduced the TC content of the blood to levels similar to the intact group.

The CLDL and CVLDL contents in the blood serum of the animals on the atherogenic diet reliably increased in the control group by 62.35 and $29.41 \%$, respectively, in comparison with those in the intact group. The CLDL level decreased by $7.59 \%$ and the CVLDL 


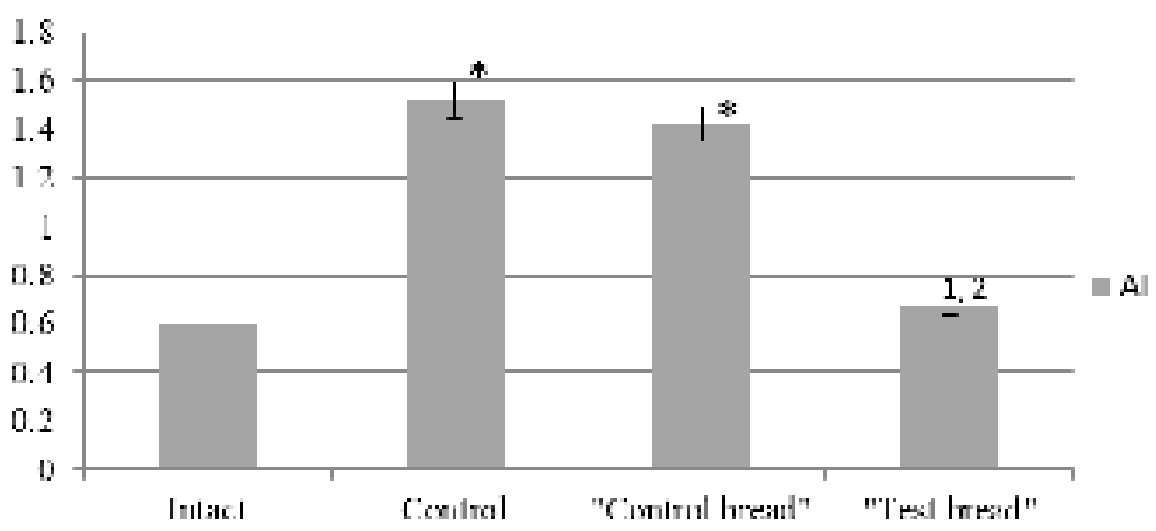

Figure 3: The atherogenic index of the experimental animals. Note: ${ }^{*}$ - reliable value deviation compared to the intact group $(\mathrm{p} \leq 0.05){ }^{1}$ - reliable value deviation in the "test bread" group compared to the value in the «control bread» group $(\mathrm{p} \leq 0.05){ }^{2}$ - reliable value deviation in the "test bread" group compared to the value in the "control bread" group $(p \leq 0.05)$.

increased by $24.45 \%$ within animals treated with bread without $\omega-3$ in comparison with the control group. The CLDL and CVLDL contents among rats treated with $\omega$-3-enriched bread decreased, respectively, by 150 and $17.24 \%$, compared to the control group. The TG content in the blood serum of the same group decreased by $15.38 \%$, whereas the content of TG among animals treated with bread without $\omega-3$ increased by $24.24 \%$ when compared with the control group. This, apparently, is connected to the high content of easily digestible carbohydrates in the diet.

The CHDL index in the blood serum of animals on the atherogenic diet (control group) decreased by $19.23 \%$ in comparison to the corresponding index of the intact group. The $\mathrm{CHDL}$ content increased by $10.34 \%$ when the animals received the control white wheat bread on the background of the atherogenic diet, while the content of $\mathrm{CHDL}$ within animals treated with $\omega$-3-enriched bread increased by $17 \%$ relative to the control group.

On the basis of the obtained results, the Al within the experimental rats was calculated. It was found that the Al among rats treated with $\omega$-3-enriched bread on the background of the atherogenic diet, decreased 2.2 times in comparison to the control group and was within close proximity to the corresponding indicator in the intact group (Figure 3).

\subsection{The accumulation of oxidation products in experimental ani- mals}

Alimentary dyslipidaemia within the experimental animals was accompanied by an increased activity in the bio-oxidation processes in the blood plasma, erythrocytes and liver of rats, as evidenced by an increase in the content of lipid oxidation products. 
TABLE 1: Contents of malondialdehyde and diene conjugates in the plasma, erythrocytes and liver of experimental animals $(n=10)$.

\begin{tabular}{|c|c|c|c|c|c|c|}
\hline Group & $\begin{array}{l}\mathrm{DC} \\
\text { plasma, } \\
\mathrm{nmol} / \mathrm{ml}\end{array}$ & $\begin{array}{l}\text { DC of ery- } \\
\text { throcytes, } \\
\mathrm{nmol} / \mathrm{ml}\end{array}$ & $\begin{array}{l}\text { DC of liver, } \\
\mathrm{nmol} / \mathrm{g}\end{array}$ & $\begin{array}{l}\text { MDA of } \\
\text { plasma, } \\
\mathrm{nmol} / \mathrm{ml}\end{array}$ & $\begin{array}{l}\text { MDA of } \\
\text { erythrocytes, } \\
\mathrm{nmol} / \mathrm{ml}\end{array}$ & $\begin{array}{l}\text { MDA of liver, } \\
\mathrm{nmol} / \mathrm{g}\end{array}$ \\
\hline Intact & $3.06 \pm 0.11$ & $14.32 \pm 0.56$ & $47.00 \pm 1.14$ & $2.27 \pm 0.09$ & $13.33 \pm 1.09$ & $37.09 \pm 0.22$ \\
\hline Control & $4.69 \pm 0.09 *$ & $16.65 \pm 0.48^{*}$ & $85.50 \pm 3.21^{*}$ & $3.48 \pm 0.06^{*}$ & $27.82 \pm 0.91^{*}$ & $91.20 \pm 0.65^{*}$ \\
\hline $\begin{array}{l}\text { "Control } \\
\text { bread" }\end{array}$ & $3.34 \pm 0.12^{1}$ & $16.12 \pm 0.65$ & $87.92 \pm 2.32$ & $3.07 \pm 0.05^{1}$ & $23.97 \pm 1.48$ & $65.80 \pm 0.36^{1}$ \\
\hline $\begin{array}{l}\text { "Test } \\
\text { bread" }\end{array}$ & $2.87 \pm 0.10^{1,2}$ & $14.78 \pm 0.16^{1,2}$ & $52.26 \pm 1.67^{1,2}$ & $2.45 \pm 0.10^{1,2}$ & $14.46 \pm 3.30^{1,2}$ & $42.60 \pm 1.52^{1,2}$ \\
\hline
\end{tabular}

It is known that the resulting lipid radicals, as well as MDA and DCs, can attack the proteins and nucleic acids. The aldehyde groups of these lipid oxidation compounds form intermolecular cross-linking, which disturbs the structure and functionality of macromolecules. Lipid oxidation leads to the disruption of the membrane bilayer organisation, which can cause damage to membrane-bound proteins (Krinsky 1988). Table 1 presents data on DCs and MDA contents in the plasma, erythrocytes and liver of the experimental animals.

Table 1 shows a decrease in the DCs content in the plasma (63.41\%), erythrocytes (12.65\%), and in liver homogenates (63.60\%) within animals treated with $\omega$-3-enriched bread compared to the control group. Regarding the final products of oxidation, the results show that the MDA content reliably decreased in the blood plasma (42\%), erythrocytes (92.39\%), and liver (114.1\%) among animals treated with test bread compared to the control group. Notably, a reliable decrease in the indicators of oxidation product accumulation was observed only for the DCs and MDA values of the plasma, as well as the MDA content of the liver, among animals treated with bread without $\bigotimes-3$ in comparison with the control group.

\subsection{The antioxidant effect of enriched bread}

In addition to investigating the oxidation processes, we examined the state of the in vivo antioxidant system. In particular, the TCA was estimated in the erythrocytes of the experimental animals.

The charts in Figure 4 reveal the TCA in the erythrocytes reliably decreased by $14 \%$ in the control group when compared with the same indicator in the intact group. This indicator increased by $7.65 \%$ among rats treated with wheat bread without $\bigotimes-3$ compared 


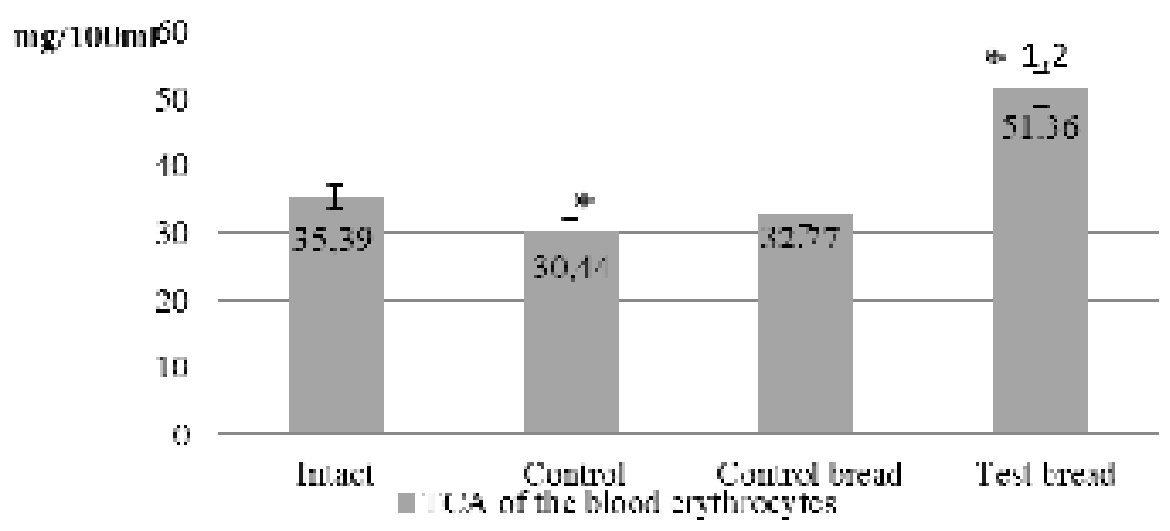

Figure 4: The total content of antioxidants in the erythrocytes of experimental animals. Note: ${ }^{*}$ - reliable value deviation compared with the intact group $(p \leq 0.05) .{ }^{1}$ - reliable value deviation in the «test bread» group compared to the value in the "control bread" group $(p \leq 0.05) .{ }^{2}$ - reliable value deviation in the «test bread» group compared to the value in the "control bread" group $(p \leq 0.05)$.

to the control group. Among animals treated with $\bigotimes$-3-enriched bread, the TCA value in the erythrocytes reliably increased by $68.73 \%$ relative to the control group and by $45.13 \%$ when compared with the intact group.

The activity of protective mechanisms during oxidative stress is associated with the antioxidant enzymes, as well as low-molecular cell components, one of which is GSH. The significance of GSH in a cell is determined by its antioxidant properties. GSH not only protects cells against toxic agents, such as free radicals, but, in general, defines the redox status of the intracellular environment. In the cell, the thiol groups are in a reduced state $(\mathrm{SH})$ at about $5 \mathrm{mM}$. Such a high concentration of GSH in a cell leads to restoration of any disulphide bond (S-S) formed between the cysteines of cytosolic proteins. In this instance, the reduced form of GSH becomes oxidised (GSSG form). Reduced GSH is a coenzyme of several enzymes, whose activity is based on the change in the redox potential of GSH, which is a direct function of the destruction of free radicals. Oxidised GSH is reduced by GSH reductase, which resides in a cell in the active state and is induced by oxidative stress [23].

The activity indices of the GSH system of the experimental animals (Table 2) demonstrated that the activity of GSH reductase reliably decreased by $58.27 \%$ within the control group animals on the atherogenic diet compared to the intact group. Consequently, the content of reduced GSH decreased by $23.37 \%$ among rats of the control group compared to the intact group.

The GSH reductase activity reliably increased by $25.38 \%$ among animals treated with bread without $\otimes-3$ on the background of the atherogenic diet compared to the indicators of the control group and the reduced GSH content decreased by $22.22 \%$. For the 
TABLE 2: The activity of glutathione reductase, the content of reduced glutathione in the blood serum of rats $(n=10)$.

\begin{tabular}{|c|c|c|c|c|c|}
\hline & Indicator & Intact & Control & Control bread & Test bread \\
\hline 1 & $\begin{array}{l}\text { Glutathione reductase, } \\
\mathrm{mmol} / \mathrm{min} / \mathrm{g} \mathrm{Hb}\end{array}$ & $45.41 \pm 1.08$ & $28.69 \pm 2.66^{*}$ & $38.45 \pm 1.34^{1}$ & $39.63 \pm 0.19^{1}$ \\
\hline 2 & $\begin{array}{l}\text { Reduced glutathione, } \\
\mathrm{nmol} / \mathrm{g} \mathrm{Hb}\end{array}$ & $9.50 \pm 0.69$ & $7.70 \pm 0.32^{*}$ & $6.30 \pm 0.42^{1}$ & $10.31 \pm 0.45^{1}$ \\
\hline
\end{tabular}

animals treated with the PUFA-enriched bread on the background of the atherogenic diet, the GSH reductase activity reliably increased by $27.61 \%$ and the reduced $\mathrm{GSH}$ content increased by $25.31 \%$ compared to the corresponding indicators in the control group. Furthermore, in the group of animals treated with $\otimes-3$-enriched bread, the reduced GSH content reached the same level as that of the intact group and the GSH reductase activity index came close to the value of the intact group.

Biological effects of $\mathbb{Q}-3$ family PUFAs are attributed primarily to their influence on the function of cell membranes and their ability to affect the properties of the membranebound receptors, signal transduction, as well as the activity of a large number of membrane-bound enzymes [30]. However, a large number of double bonds in the

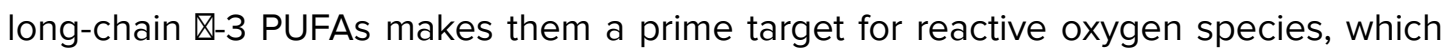
facilitates lipid peroxidation processes and increases the probability of oxidative stress development [34].

Nonetheless, besides exhibiting prooxidant properties, PUFAs can also be effective antioxidants [15]. According to Kravchenko [21] the antioxidant effect of $\bigotimes-3$ PUFAs is a result of both their radical binding capacity and their impact on the antioxidant enzyme activity. Our findings point to a recovery of the antioxidant capacity in the animals treated with $\bigotimes$-3-enriched bread, following an atherogenic diet.

\section{Conclusion}

We studied the hypolipidaemic and antioxidant effects of wheat bread enriched with a liposomal PUFAs concentrate in animals with experimentally-induced alimentary hyperlipidaemia. The lipid profile of the blood serum of the laboratory animals showed that the inclusion of $\omega$-3-enriched bread on the background of the atherogenic diet decreased the TC, as well as the pro-atherogenic fractions of lipoproteins (LDL and VLDL). In this instance, the anti-atherogenic fractions ( $\mathrm{CHDL}$ ) increased, indicating the hypolipidaemic effect of the food product. In addition to improving lipid metabolism, positive dynamics 
in the antioxidant status of the animals treated with the $\omega$-3-enriched product was observed. Thus, bread enriched with liposomal PUFAs concentrate can be marketed as a functional food with hypolipidaemic action.

\section{Declaration of Interest}

The authors report no conflict of interest. The authors alone are responsible for the content and writing of the manuscript.

\section{References}

[1] Akbarzadeh A, Rezaei-Sadabady R, Davaran S et al. Liposome: Classification, preparation, and applications. Nanoscale Research Letters. 2013;8:9-11

[2] Averina ES, Kutyrev IA. Perspectives on the use of marine and freshwater hydrobiont oils for development of drug delivery systems. Biotechnology Advances. 2011;29:548-557.

[3] Beutler E, editor. Red cell metabolism, a manual of biochemical methods. New York: Grune and Straton; 1975.

[4] Bligh EG, Dyer WJ. A rapid method for total lipid extraction and purification. Canadian Journal of Biochemistry and Physiology 1959;37:911?917.

[5] Buttriss J. Are health claims and functional foods a route to improving the nation's health? Food and Nutrition Bulletin. 2010;35:87?91.

[6] Cardoso SM, Pereira OR, Seca AML, Pinto DCGA, Silva AMS. Seaweeds as preventive agents for cardiovascular diseases: From nutrients to functional foods. Marine Drugs. 2015;13:6838?6865.

[7] Chaudhry Q, Scotter M, Blackburn J et al. Applications and implications of nanotechnologies for the food sector. Food Additives and Contaminants Part A Chem Anal Control Expo Risk Assess. 2008;25:241?258. doi: 10.1080/02652030701744538.

[8] Chowdhury R, Warnakula S, Kunutsor S et al. Association of dietary, circulating, and supplement fatty acids with coronary risk: A systematic review and meta-analysis. Annals of Internal Medicine. 2014;160:398-406. doi:10. 7326/m13-1788.

[9] de Assis AM, Rech A, Longoni A et al. Omega-3 polyunsaturated fatty acids prevent lipoperoxidation, modulate antioxidant enzymes, and reduce lipid content but do not alter glycogen metabolism in the livers of diabetic rats fed on a high fat thermolyzed diet. Molecular and Cellular Biochemistry. 2012;361:151-160. doi: 10.1007/s11010-011$1099-4$. 
[10] de Conto LC, Oliveira RSP, Martin LGP, Chang YK, Steel CJ. Effects of the addition of microencapsulated omega-3 and rosemary extract on the technological and sensory quality of white pan bread. LWT - Food Science and Technology. 2012;45:103?109. doi: 10.1016/j.lwt.2011.07.027.

[11] Ernster L, Nordenbrand K. Microsomal lipid peroxidation. Methods in Enzymology. 1967;10:574?580.

[12] Ganesan B, Brothersen C, McMahon DJ. Fortification of foods with omega3 polyunsaturated fatty acids. Critical Reviews in Food Science and Nutrition 2014;54:98?114. doi:10.1080/10408398.2011.578221.

[13] Garg ML, Wood LG, Singh H, Moughan PJ. Means of delivering recommended levels of long chain n-3 polyunsaturated fatty acids in human diets. Journal of Food Science2006;71:66?71.

[14] Gavrilov VB, Mishkorudnaya MI. Spektrofotometricheskoye opredeleniye soderzhaniya gidroperekisey lipidov $v$ plazme krovi [Spectrophotometric determination of lipid hydroperoxides in blood plasma]. Lab Delo. 1983;3:33?36.

[15] Giordano E, Visioli F. Long-chain omega 3 fatty acids: Molecular bases of potential antioxidant actions. Prostaglandins Leukot Essent Fatty Acids. 2014;90:1-4. http://dx.doi.org/10.1016/j.plefa.2013.11.002.

[16] Glatzle D, Vuilleumier JP, Weber F, Decker K. Glutathione reductase test with whole blood, a convenient procedure for the assessment of riboflavin status in humans. Cellular and Molecular Life Sciences. 1974;30:665?667.

[17] Gómez-Candela C, Bermejo-López LM, Loria-Kohen V. Importance of a balanced omega 6/omega 3 ratio for the maintenance of health. Nutritional recommendations. Nutrición Hospitalaria2011;26:323?329.

[18] Grahl-Nielsen O, Halvorsen A-K, Bodoev N et al. Fatty acid composition of blubber of the Baikal seal Phoca sibirica and its marine relative, the ringed seal $P$. hispidaMarine Ecology Progress Series. 2005;305:261-274.

[19] James MJ, Gibson RA, Cleland LG. Dietary polyunsaturated fatty acids and inflammatory mediator production. The American Journal of Clinical Nutrition. 2000;71:343-348.

[20] Kaushik P, Dowling K, Barrow CJ, Adhikari B. Microencapsulation of omega-3 fatty acids: A review of microencapsulation and characterization methods. Journal of Functional Foods. 2015;19:868?881. doi: 10.1016/j.jff.2014.06.029.

[21] Kravchenko LV, Aksenov IV, Avren'eva LI, Beketova NA, Trusov NV, Guseva GV. Vliyaniye polinenasyshchennykh zhirnykh kislot omega-3 na nekotoryye pokazateli antioksidantnogo potentsiala krys [The influence of omega-3 polyunsaturated fatty 
acids on some indicators of the antioxidant capacity of rats]. Voprosy Pitaniya. 2013;82:4?9.

[22] Krinsky NI. Membrane antioxidants. Annals of the New York Academy of Sciences. 1988;551:17?32.

[23] Kulinskij VI, Kolesnichenko LS. Sistema glutationa I. Sintez, transport glutationtransferazy, glutationperoksidazy [The glutathione system. I. Synthesis, transport, glutathione transferases, glutathione peroxidases]. Biomedicinskaya Khimiya. 2009;55:255?277.

[24] Lamazhapova GP, Syngeeva EV, Kozlova ?S, Zhamsaranova SD. Razrabotka liposomal'noy formy kontsentrata polinenasyshchennykh zhirnykh kislot: vozmozhnyye puti ispol'zovaniya pri proizvodstve funktsional'nykh pishchevykh produktov [Development of a liposomal form of a concentrate of polyunsaturated fatty acids: possible ways of using in the production of functional food products]. Voprosy Pitaniya. 2017;86:80-88.

[25] Metodicheskiye rekomendatsii MP 2.3.1.2432-08. Normy fiziologicheskikh potrebnostey $v$ energii i pishchevykh veshchestvakh dlya razlichnykh grupp naseleniya Rossiyskoy Federatsii (utv. Glavnym gosudarstvennym sanitarnym vrachom RF 18 dekabrya 2008) [Methodical recommendations MP 2.3.1.2432-08. Norms of physiological needs for energy and nutrients for different population groups of the Russian Federation (approved by the Chief State Sanitary Doctor of the Russian Federation on December 18, 2008]. Ekologicheskiye Vedomosti. 2009;March;3:6?42.

[26] Mihara M, Uchiyama M, Fukuzawa K. Thiobarbituric acid value on fresh homogenate of rat as a parameter of lipid peroxidation in aging, $\mathrm{CCl} 4$ intoxication, ?nd vitamin $\mathrm{E}$ deficiency. Biochemia Medica1980;23:302?311.

[27] Placer Z. Lipoperoxydationssysteme im biologischen Material 2. Bestimmung der Lipoperoxydation im Säugetierorganismus [Lipoperoxidation systems in biological material 2. Determination of lipoperoxidation in the mammalian organism]. Nahrung. 1968;12:679?684.

[28] Riediger ND, Othman RA, Suh M, Moghadasian MH. A systemic review of the roles of $n-3$ fatty acids in health and disease. Journal of the American Dietetic Association. 2009;109:668?679.

[29] Ruiz JCR, Vazquez EDLLO, Campos MRS. Encapsulation of vegetable oils as source of omega-3 fatty acids for enriched functional foods. Critical Reviews in Food Science and Nutrition2017;57:1423?1434. doi: 10.1080/10408398.2014.1002906. 
[30] Rustan AC, Drevon CA. Fatty acids: Structures and properties. Encyclopedia of Life Sciences. 2005: 1. 1-7. doi: 10.1038/npg.els.0003894

[31] Sanguansri L, Day L, Shen Z et al. Encapsulation of mixtures of tuna oil, tributyrin and resveratrol in a spray dried powder formulation. Food and Function Journal 2013;4:1794?1802. doi:10.1039/C3FO60197H.

[32] Bresson, Jean-Louis \& Flynn, Albert \& Heinonen, Marina et al. Scientific opinion of the panel on dietetic products, nutrition and allergies on a request from European Commission related to labeling reference intake values for $n-3$ and $n-6$ polyunsaturated fatty acids. European Food Safety Agency Journal. 2009;1176:1?11.

[33] Taylor TM, Weiss J, Davidson PM, Bruce BD. Liposomal nanocapsules in food science and agriculture. Critical Reviews in Food Science and Nutrition. 2005;45:587?605.

[34] Visioli F, Galli C. Evaluating oxidation processes in relation to cardiovascular disease: a current review of oxidant/antioxidant methodology Nutrition Metabolism and Cardiovascular Diseases. 1997;7:459-466.

[35] Vladimirov Y?, Archakov Al. Perekisnoye okisleniye lipidov $v$ biologicheskikh membranakh [Lipid peroxidation in biological membranes]. Moscow: Nauka; 1972.

[36] World Health Organization. Global health risks: Mortality and burden of disease attributable to selected major risks. Geneva: World Health Organization; 2009.

[37] Zhamsaranova SD, Lamazhapova GP, Syngeeva EV. Development of a method to produce a concentrate of polyunsaturated fatty acids. BIOSCIENCES BIOTECHNOLOGY RESEARCH ASIA. 2014;11:59?64.

[38] Zhamsaranova SD, Lamazhapova GP, Syngeeva EV, Burnasheva EV. The effect of the concentrate of polyunsaturated fatty acids on indicators of oxidative stress in experimental dyslipidemia. Bulletin of experimental biology and medicine. 2015;7:106-15. 